\title{
Tracking the pre-service teachers' development of communicative skills and their beliefs towards communicative approach
}

\author{
Yıldıray Kurnaz ${ }^{1}$ and Ali Şükrü Özbay² \\ ${ }^{1}$ Department of Foreign Languages, Bayburt University, Turkey (ORCID: 0000-0001-8762-9749) \\ 2Department of Western Languages and Literature, Karadeniz Technical University, Turkey (ORCID: 0000-0002-3421-0650)
}

\begin{abstract}
Concerns about the purpose of developing communicative skills in English teaching and approaches to overcome these concerns have always had an important place in language teaching. In this context, besides the fact that teachers' roles are important, their beliefs about the approach have a profound influence on their professional achievement. In this regard, the aim of the present study was to determine Turkish English as a Foreign Language (EFL) student teachers' beliefs about developing their communicative skills with the communicative approach in Turkish context. The data obtained through Pre-Service Teacher Beliefs Questionnaire, in which 445 participants took part, and focus group interviews with 28 participants at several times and places were analysed by quantitative and qualitative data analysis methods respectively. As a result of the analysis, it was found that EFL student teachers generally had positive attitudes towards improving communicative skills of their prospective students with communicative approach; however, it was difficult for this approach to work properly in Turkey and in Turkish education system due to various reasons. In addition, it was found that EFL student teachers' selfefficacy beliefs were correlated with their attitudes towards the approach, and that many sub-factors such as second language proficiency also had an influence on the attitudes. Lastly, these findings were found to be significantly different according to the departments (ELL, ELT) rather than age and gender.
\end{abstract}

Keywords: Communicative approach; Communicative skills; Student teachers; EFL; Beliefs

Article History: Submitted 22 August 2020; Revised 21 October 2020; Published online 23 October 2020

\section{Introduction}

While the developing technology eliminates the time and place concepts through leading to rapid globalization (Beck, 2002; Oral, 2003), not only in political but also in academic aspects (Altan, 2010), English language has evaluated and dominated most parts of the world (Altan, 2010; Altan, 2017a; Bottery, 2000; Chang, 2006). The spread of English as a lingua franca had not been experienced by any other languages before (Crystal, 2003; Kachru, 1986; Swales, 1997). In this direction, Turkish Ministry of Education carried out the "The Ministry of Education Development Project" in 1997 for increasing the significance of English language teaching in the formal education system in addition to taking the first step into replacing the traditional methods with the

\footnotetext{
Address of Corresponding Author

Ali Şükrü Özbay, PhD, Department of Western Languages and Literature, Faculty of Letters, English Language and Literature, Kanuni Campus, 61080, Trabzon, Turkey.

$\triangle$ alisukruozbay@gmail.com
}

How to cite: Kurnaz, Y., \& Özbay, A. Ş. (2020). Tracking the pre-service teachers' development of communicative skills and their beliefs towards communicative approach. Journal of Pedagogical Research, 4(3), 223-240. 
more student-centred ones (Kırkgöz, 2007). However, English language teaching in Turkey has not reached the desired level, yet. While the ultimate target of the regulations such as starting foreign language education and increasing the English chapters of fifth grade in number and content to turn it into a foreign language preparation class in the future as Altan (2017b) claims began at 2nd grade, it still seems to lack effective use of communicative approach. As Akpınar and Aydin (2010) argues, the problem of foreign language teaching in Turkey may be more complicated than the consideration of age or the amount of exposure since even the learners who study a foreign language more than ten years achieve nothing more than a little grammar. For the very reason, considering the four aspects of communicative competence including grammatical competence, discourse competence, sociolinguistic competence and strategic competence (Bachman, 1990; Brown, 2000; Byram, 1997; Canale \& Swain, 1980; Celce-Murcia \& Dornyei, 2014; Hymes, 1971, 1972; Liao, 1997; Savignon, 1983; Skehan, 1998; Weir, 1998), it is essential to state that the lack of Turkish language learners' communicative competence arises from other competences except for grammatical competence.

At this point, as they are implementers of the policies suggested and put into practice, focus turns towards the teachers. According to Özoğlu (2010), education faculties are insufficient in terms of not only physical environments but also human resources. The most important basis of this insufficiency arises from the fact that EFL student teachers may not be exposed to the target language during their teacher education. The terms "pre-service teachers" and "student teachers" were used interchangeably in the study. Even though some pre-service EFL teachers in some universities can have the chance to have native speaker instructors at their departments, most of them graduate without facing a native speaker instructor during their teacher education. All these reasons may lead them to negative ideas about the program they are enrolled and the beliefs they have towards the language they will teach and the approach they are going to implement in the future. Considering the problems of foreign language teaching in Turkey, what kinds of beliefs Turkish pre-service EFL teachers have about communicative skills development and communicative approach in Turkish context was investigated within the present study. As their beliefs about their teaching profession could not be based on actual teaching experiences due to their lack of field-work, pre-service EFL teachers' beliefs and ideas about teaching can be considered as their future expectations influenced by their learning experiences and observations during their education life. So, it could be said that pre-service EFL teachers' negative prior learning experiences may lead to negative prejudices towards teaching (Horwitz, 1985; Mak, 2011; Pajares, 1992; Zheng, 2009). EFL students and teachers need to be more focused on how they develop their beliefs and what factors determine their beliefs in the context of foreign language learning (Raoofi et. al., 2012).

\subsection{Communicative Approach (CA) and Teacher Belief}

Apart from some counter-discoursing minor groups, a high percentage of English teachers today claim that they give much importance to developing communicative skills and therefore prefer to make use of the communicative approach in the classroom. Yet, it is a question of fact whether they are well-informed about what the communicative approach (CA) is. CA is an approach designed to foster foreign or second language teaching through communicative competence (Richards, 1992, 2006). Focusing on meaningful communication rather than structural patterns (Hui \& Jin, 2010) and perceiving the main aim of language teaching as developing communicative skills (Liao, 1997), CA puts learners into such a central position where they are expected to be highly active in constant communication with others around while the teacher acts as the counsellor, guide, organizer, and facilitator of the process (Liao, 1997). In this sense, Breen and Candlin (1980) argued the role of teachers as not only facilitating the communication process among the participants in the classroom through organizing a variety of activities and texts but also acting in an independent manner within the learning-teaching process. Teachers' role in a learning-teaching environment is claimed to be shaped by their teaching perceptions and 
preferences about a subject. Yet, to be able to comment on the teaching perceptions and preferences of teachers, their attitudes need to be investigated. In this context, teachers' perceptions, attitudes towards learning and teaching processes, and thus, their classroom preferences can be claimed to be influenced by their beliefs about teaching. For the purpose of developing in-service teachers' in-class performances, or developing pre-service teachers' trainings, focusing on and understanding teachers' belief systems seem to have a crucial emphasis (Bauch, 1982; Brookhart \& Freeman, 1992; Buchmann, 1984; Clark, 1988; Enochs \& Riggs, 1990; Fang, 1996; Goodman, 1988; Haney et al., 2002; Levin \& Wadmany, 2005; Pajares, 1992; Wilson, 1990; Woolley, et al., 2004). Because the roles and responsibilities of teachers, their professional values and ethical principles, their decisions on planning, implementing and evaluating a teaching process, and their class management skills can be shaped by their beliefs about education. Accordingly, Dijk (2014) argues that having a grasp of just language system including grammar and vocabulary could not be enough for a language teacher. The two belief systems of EFL teachers including curriculum beliefs and language acquisition beliefs have a direct influence on EFL teachers' teaching performances through their decision-making preferences, behaviours and interactions with students while their knowledge base has an indirect influence on their teaching process. Accordingly, Hunter (1982) argued that teaching is "a constant stream of professional decisions made before, during, and after interaction with the student" and that "students learn more through effective teaching than when they try to learn on their own" (p. 5).

Various studies have been conducted so far to shed light on the discussions and these studies revealed empirical data about the efficiency of CA in Turkish formal education context. Among these, there are some research-based studies revealing the current condition of CA in Turkish context. To begin with, Bağçeci (2004) found that half of the students participating in their study claimed not to be pleased with the way they were thought English within the scope of communicative purposes. The subjects complained about the unattractiveness of the English classes and the lack of supportive material. In another experimental study, Tayhani-Temizgöl (2013) carried out with 50 tenth grade students in 2011-2012 academic year, the participants were asked to take a pre-test and a post-test before and after the experiment which took four weeks. The result was that CA was found to be more effective than grammar-translation method (GTM) in terms of vocabulary teaching. In yet another study, a comparison between CA and GTM in terms of how influential they are on students' achievement was made and tenth-grade students participated in the study and Temizöz (2008) found that the quantitative data again revealed the superiority of CA over GTM. Additionally, in his study carried out with 52 sixth grade students, Aktimur (2007) found that teaching specific skills integrated through pair work or group work yielded much better results when compared to traditional ways. Also, the study conducted by Altınuç (2012) with 5 English teachers with the purpose of finding out the beliefs of English teachers"e about CA in Turkey revealed that crowded classes, insufficient time for extra studies or works for a better reflection to the learning-teaching process and central exam anxiety were the issues mostly complained by the participants in the implementation of CA in their classes.

Regarding the problems generally associated with CA, Özşevik (2010) revealed that Turkish EFL teachers faced various, problems originating from teachers, students, Turkish educational system or the CA itself during the implementation. Despite their positive attitudes towards it, participants of the study claimed to be pessimistic about CA under present conditions. In her study with 150 beginner level undergraduate and graduate students, Emeli (1999) found that not only their practices but also the teachers' beliefs were not in accordance with the requirements of CA. The influence of the professional experience and English self-efficacy beliefs of 48 English instructors working at a state university was analysed by Aliş (2008). The study showed that the participant instructors' self-efficacy beliefs and their attitudes towards CA were directly proportional. Furthermore, Çimen (2008) studied with 14 teachers from different secondary and high schools. The results of the study revealed that novice teachers were more aware of the theoretical background of CA when compared to the more experienced ones. Additionally, 
Soğuksu (2013) found that applicability of CA in Turkish formal education at government schools is claimed to be hard under the present conditions because of the number of students, seat orders, lack of materials etc. Also, in a study with a similar purpose to investigate the footsteps of CA in classroom environment conducted by Şeker and Aydın (2011) with tenth, eleventh and twelfthgrade students, it was found that there was a big gap between the targets of the curriculum and the learning output. After collecting data from 307 undergraduates via a questionnaire, Yilmaz (2005) found that the student teachers were seen unable to use the foreign language in an efficient way for communicative purposes and the present teaching programs were not sufficient in terms of improving their communicative language skills. Last but not least, the data obtained from 24 Turkish EFL student teachers by Akyel (2015) revealed that the participants make use of practice teaching and research engagement during their school practicum.

\subsection{EFL Teachers in Communicative Approach}

Regarding their operational roles in the classrooms, CA teachers are defined as being facilitators, group process managers, needs analysts and counsellors (Richards \& Rodgers, 2001). However, the suggested facilitator role of the teacher recommending minor teacher talk while promoting more and more student talk during the classes could be handled carefully for avoiding another unexpected problem resulting from the less teacher talk. The activities of CA for classroom interaction "forgoes much of the familiar and requires something different" (Deckert, 1987) as the students' native language (the familiar one) does not make much sense during the classes (LarsenFreeman, 2000), and therefore, the target language becomes the communication tool during activities in addition to classroom management by the teachers (Celce-Murcia, et. al., 2020) providing students with meaningful real-life exposure suggested by Hui and Jin (2010). Also, the way a teacher behaves in the implementation of a method depends on his or her beliefs about it (Richards, 2006). So, the development of communicative skills can only take place if learners have motivation and opportunities to express their own identities and to relate with the people around them (Littlewood, 1981). All these claims underline the emphasis of the teachers' beliefs and professional knowledge base referring to the teachers' both field and pedagogic capabilities gained during the teaching training program.

\subsection{The Study}

The present study aims to determine Turkish pre-service EFL teachers' beliefs towards developing their prospective students' communicative skills with the communicative approach in Turkish context. Furthermore, the ultimate aim of the present study is to raise some suggestions and implications for pre-service teacher training programs regarding possible concerns and drawbacks of pre-service EFL teachers about developing their future students' communicative competences in Turkish EFL context. In this context, the following questions were asked in light of the quantitative and qualitative data:

1. What are Turkish EFL student teachers' ideas about communicative competence?

2. What are Turkish EFL student teachers' beliefs about the communicative approach and its practicality in Turkish formal education system?

3.3. To what extent do Turkish EFL student teachers feel self-efficient in communicative approach?

3.1. Is there any difference between EFL student teachers' beliefs on the basis of gender, department and age group varieties?

3.2. Is there any correlation among EFL student teachers' beliefs about the communicative approach, their self-efficacy beliefs in their EFL skills and in their knowledge of the communicative approach?

\section{Method}

This is a descriptive study of an exploratory nature which includes both qualitative and quantitative data collection methods as parts of the triangulation. Triangulation is defined as 
applying more than one methodology in a study or making use of two or more methods for collecting data for the purpose of analysing human attitudes (Cohen \& Manion, 1994).

\subsection{Participants}

Participants of the study were selected from senior degree pre-service EFL teachers. As the questionnaires and focus group interviews were conducted at both English Language Teaching (ELT) and English Language and Literature (ELL) departments, participants planning to be teachers after graduation were included in the study. Furthermore, since the participants were senior degree pre-service EFL teachers, their language levels were expected to be at either upperintermediate or advanced levels, considering the proficiency expectations from the students of Foreign Language Education Departments nationwide. Also, participant students had completed their pedagogical formation training before participating in the present study.

For sampling, convenience sampling was preferred for practicality, availability and easy accessibility (Dörnyei \& Taguchi, 2009). 445 students in total from ELT and ELL departments of 8 state universities located in Marmara, Aegean, Central Anatolia, Black Sea, Eastern and Southeastern regions of Turkey participated in the survey. Distribution of the participants in relation to their universities is as A (46 ELL, 13 ELT), B (48 ELT), C (32 ELL, 39 ELT), D (52 ELL, 19 ELT), E (38 ELT), F (36 ELT), G (48 ELL) and H (33 ELL, 41 ELT). Among all, 5 universities were old ones with more than 40 years of foundation date while 3 were middle size universities founded at least 20 years ago.

\subsection{Research Instruments}

In this mixed-method study, we aimed to gain an insight into Turkish EFL student teachers' beliefs towards communicative skills development and communicative approach in Turkish formal context. Both qualitative and quantitative data analysis procedures were carried out in the present study. In order to gather quantitative data, the questionnaire developed by Nishino (2012) to investigate the teachers' perceptions and practices regarding CA, and the relationships among their beliefs, practices, and other variables were used. While Nishino's study was investigating the perceptions of actively working teachers, the present study sought answers to pre-service teachers' expectations about particular external factors such as students and school environments and some questions were adapted. The questionnaire designed in a 5 Likert scale included 17 items. In terms of test reliability, Cronbach's Alpha coefficient item reliability was .876. In the first section of the questionnaire, questions related to beliefs about CA were asked. In the second section, questions related to participants' self-efficacy beliefs in their foreign language skills were asked. In the third section, the questions were related to pre-service teachers' self-efficacy beliefs in CA. The questionnaire in this study was piloted for three times on ten samples. The samples consisted of five third grade ELT students, third grade ELL students and 2 English instructors from three different state universities in total. They were asked to respond to the questionnaires and reflect on any question that they thought should be modified or omitted. After the first treatment and modifications, the three ELL students were asked to pilot. In this second piloting, they suggested some modifications as well. Upon the final piloting, carried out with the two lecturers, additional changes were made. This process of piloting lasted three weeks.

On the other hand, the qualitative data was obtained via four focus group interviews organized and guided in line with the questions prepared by the researchers considering the purpose of the present study.

\subsection{Data Collection}

The quantitative data was collected from 445 students through the pre-service teacher questionnaire mentioned in the previous part. For the qualitative data, four focus-group interviews were held with 28 participants. Each of the four interviews was held in different places with different participants. The interviews were held in peaceful and sincere environments owing to meeting the participants earlier than the interview hour and spending some time together to talk 
about daily issues for breaking the possible ice between the participants and the researcher. Each interview was recorded within each participant's knowledge by the researcher, using two different audio recorders simultaneously to avoid losing any part of the data due to possible technical problems during recordings.

Among 445 pre-service EFL teachers who participated in the questionnaire 19 female and 9 male pre-service EFL teachers participated in the focus group interviews with a total number of 28 . Distribution of the participants and durations of the four focus groups interviews are shown in Table 1.

Table 1.

Focus Group Interview Participants and Durations

\begin{tabular}{lclcc}
\hline & Department & Gender & Group Size & Duration \\
\hline 1.Focus Group interview & ELT & $\begin{array}{l}\text { 4 Female } \\
\text { 2 Male }\end{array}$ & 6 & 42 Minutes \\
2.Focus Group Interview & ELT & $\begin{array}{l}\text { 6 Female } \\
\text { 3 Male }\end{array}$ & 9 & 46 Minutes \\
6.Focus Group Interview & ELL & $\begin{array}{l}\text { 6 Female } \\
\text { 2 Male } \\
\text { 3.Female }\end{array}$ & 8 & 51 Minutes \\
4.Focus Group Interview & ELL & 5 & 38 Minutes \\
\hline
\end{tabular}

\subsection{Data Analysis}

The numerical data obtained from 445 participants through the questionnaire were coded and entered into SPSS software and analysed. Comparison of internal variables between two independent variables was conducted with a Mann Whitney U Test, and comparisons between more than two groups were carried out via Kruskal Wallis due to the non-parametric nature of the data. Additionally, an expert on statistics was consulted and cooperated with during the analysis process for reducing the risk in analysis and interpretation. The qualitative data collection tool was focus-group interviews which were firstly transcribed and translated into English. Content analysis of the interviews was made after categorizing the data in accordance with the research questions and certain themes emerged from the data. For analysing the data collected, transcribed and translated, the four steps of content analysis suggested by Şimşek and Yıldırım (2011) were followed. The four-step analysis includes coding data, determining themes, organizing the codes and the themes, and defining and interpreting the data. Also, data coding is divided into three according to the way it is conducted. Among the three types of data coding, coding according to pre-determined concepts, coding according to the concepts inferred from the data, and coding within an overall frame (Şimşek \& Yıldırım, 2011), data coding in the present study was processed in parallel with coding according to pre-determined concepts.

\section{Results}

We analysed and presented the data qualitatively and quantitatively. Table 2 below shows some differences among the agreement levels of different genders, departments and age groups with beliefs about CA, self-efficacy beliefs in EFL skills and self-efficacy beliefs in CA. The mean scores of 234 female Turkish EFL student teachers from both departments with regards to beliefs about CA is $\bar{X}=4.10$, while the mean scores of 211 male pre-service EFL teachers from both departments with regards to beliefs about CA is $\bar{X}=4.12$. 
Table 2 .

Descriptive Statistics by Gender, Department and Age Group

\begin{tabular}{|c|c|c|c|c|c|}
\hline & & & $\begin{array}{c}\text { Beliefs } \\
\text { about CA }\end{array}$ & $\begin{array}{c}\text { Self-Efficacy } \\
\text { Beliefs in EFL skills }\end{array}$ & $\begin{array}{c}\text { Self-Efficacy Beliefs } \\
\text { in CA }\end{array}$ \\
\hline \multirow{9}{*}{$\begin{array}{l}\overline{\vec{U}} \\
\overline{\tilde{U}} \\
\tilde{U}\end{array}$} & \multirow{3}{*}{ Female } & Mean & 4.109 & 4.307 & 3.804 \\
\hline & & $\mathrm{N}$ & 234 & 234 & 234 \\
\hline & & SD & .451 & .491 & .525 \\
\hline & \multirow{3}{*}{ Male } & Mean & 4.122 & 4.311 & 3.810 \\
\hline & & $\mathrm{N}$ & 211 & 211 & 211 \\
\hline & & SD & .439 & .454 & .517 \\
\hline & \multirow{3}{*}{ Total } & Mean & 4.115 & 4.309 & 3.807 \\
\hline & & $\mathrm{N}$ & 445 & 445 & 445 \\
\hline & & SD & .445 & .473 & .521 \\
\hline \multirow{9}{*}{ 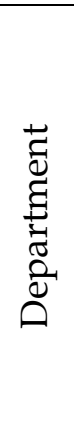 } & \multirow{3}{*}{ ELL } & Mean & 4.008 & 4.345 & 3.722 \\
\hline & & $\mathrm{N}$ & 211 & 211 & 211 \\
\hline & & SD & .422 & .474 & .553 \\
\hline & \multirow{3}{*}{ ELT } & Mean & 4.213 & 4.279 & 3.883 \\
\hline & & $\mathrm{N}$ & 234 & 234 & 234 \\
\hline & & SD & .443 & .472 & .478 \\
\hline & \multirow{3}{*}{ Total } & Mean & 4.115 & 4.309 & 3.807 \\
\hline & & $\mathrm{N}$ & 445 & 445 & 445 \\
\hline & & SD & .445 & .473 & .521 \\
\hline \multirow{12}{*}{ 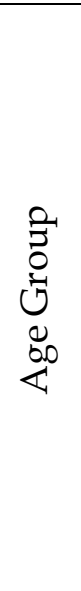 } & \multirow{3}{*}{$20-22$} & Mean & 4.176 & 4.339 & 3.739 \\
\hline & & $\mathrm{N}$ & 172 & 172 & 172 \\
\hline & & SD & .355 & .379 & .459 \\
\hline & \multirow{3}{*}{$23-25$} & Mean & 4.088 & 4.299 & 3.856 \\
\hline & & $\mathrm{N}$ & 258 & 258 & 258 \\
\hline & & SD & .495 & .528 & .558 \\
\hline & \multirow{3}{*}{$26+$} & Mean & 3.895 & 4.133 & 3.733 \\
\hline & & $\mathrm{N}$ & 15 & 15 & 15 \\
\hline & & SD & .339 & .423 & .447 \\
\hline & \multirow{3}{*}{ Total } & Mean & 4.115 & 4.309 & 3.807 \\
\hline & & $\mathrm{N}$ & 445 & 445 & 445 \\
\hline & & SD & .445 & .473 & .521 \\
\hline
\end{tabular}

With regards to their self-efficacy beliefs about their EFL skills, female participants' mean score is $\bar{X}=4.30$ while it is $\bar{X}=4.31$ for males. With regards to their self-efficacy beliefs in their CA competence, female participants' mean score is $\bar{X}=3.80$ while it is $\bar{X}=3.81$ for males

The mean scores of 234 Turkish EFL student teachers from ELT departments with regards to their beliefs about CA is $\bar{X}=4.21$, while the mean scores of 211 pre-service EFL teachers from ELL departments with regards to their beliefs about CA is $\bar{X}=4.00$. With regards to their self-efficacy beliefs about their EFL skills, ELT students' mean score is $\bar{X}=4.27$ while it is $\bar{X}=4.34$ for ELL students. With regards to their self-efficacy beliefs in their CA competence, ELT students' mean score is $\bar{X}=3.88$ while it is $\bar{X}=3.72$ for ELL students. The mean scores of 172 Turkish EFL student teachers aging between 20-22 from both departments with regards to their beliefs about CA is $\bar{X}=4.17$, while the mean scores of 258 pre-service EFL teachers aging between 23-25 from both departments with regards to their beliefs about CA is $\bar{X}=4.08$, and the mean scores of 15 preservice EFL teachers over 26 from both departments with regards to their beliefs about CA $\bar{X}=3.09$ for. With regards to their self-efficacy beliefs about their EFL skills, mean score of those between 20-22 is $\bar{X}=4.33$ while it is $\bar{X}=4.29$ for those between 23-25, and 4.13 for those over 26 . 
With regards to their self-efficacy beliefs in their CA competence, mean score of those between 2022 is $\bar{X}=3.73$ while it is $\bar{X}=3.85$ for those between 23-25, and 3.73 for those over 26 .

\subsection{Turkish EFL Student Teachers' Ideas about Communicative Competence}

There were various responses to this question depending on their perceptions about it. The most frequent response (f.10) was "expressing ideas in one way or the other". This is followed by "Discourse competence is important" (f.11) and several other participants (f.10) also responded as the following: "It is enough just to be able to express message whether in correct way or not".

P1: "Of course, accuracy is important. But in my opinion, it is the ability to express oneself in a way, rather than giving full attention to speaking correctly. If a person can sometimes make mistakes while speaking in their mother tongue, mistakes in the foreign language must be able to be ignored. The important thing is that someone can express himself / herself to the other side."

P2: If we think about the tourists coming to our country, for example, they can make a great mistake in their conversations and speak very well about what they mean to us, without speaking Turkish well. Structural errors, especially in foreign language learning, can be ignored in the first place.

P8: I do not know what the theory says about it, but I think that it can be evaluated in the sense that a student speaks fluently, or feels at a level that he or she can speak, could mean that the student has communicative competence. The situation may be different in the mother's course, of course. But speaking correctly without making any grammatical mistakes could be underestimated in foreign language.

P15: Being able to express the ideas regardless of the rule.

P27: Of course speaking without error is a sign of competence. Yet, it is not a measure of being communicatively competent. Being communicatively competent is a way of expressing a message to the recipient. While speaking fluently and regularly is a luxury, communicating the message is an impetus and may show competence.

P28: It is the level of mutual perception of the message.

However, beliefs of the participants in terms of grammatical and fluency concerns varied as 5 participants emphasized grammatical competence while 6 of them stated that fluency is more important than grammatical correctness. Further, when their ideas about the emphasis of communicative competence in Turkish formal context were asked, the participantse answers varied to some degree depending on their beliefs about the issue. Yet, some ideas showed similarities for 28 participants. The most common thought of the participants is that central examinations have an indisputably negative influence on communicative competence. 19 of the participants uttered statements in parallel with the theme that "Central examinations have a negative influence". Also, 15 of the participants shared the idea that "Concern for future leads to focus on central examinations". So, "the concern for central examination arising from the future anxiety should be a matter of concern to be solved for better communicative competence within Turkish formal education system" is the most common idea of Turkish pre-service EFL teachers interviewed.

P3: Obviously, although I think that there is a positive progress in this respect compared to old times, I think that it is difficult to be successful in public schools because of the reasons such as central examination stress and the economic reasons such as the crowded classes.

P11: I do not think developing communicative competence could not be considered in a futureoriented education system.

P19: Although we are about to graduate, it may be difficult for us to move our students forward in this regard, since we are inadequate in terms of communicative competence. The current education system aims at preparing our students for exams instead of making it possible for us to improve ourselves in this way.

Additionally, their ideas about their previous education life, especially at secondary and high schools, the participants mostly shared the idea that development of their speaking and listening skills was mostly underestimated. 10 participants uttered statements similar to the idea that 
"Grammatical competence has generally been emphasised mostly"; and 10 other speeches were uttered revealing the theme "Speaking was generally ignored during my previous education". To give some example to the statements of some students from different settings about the subject:

P1: When I consider the education I have received in the past years, we were exposed to grammatical education methods instead of communicative activities. When I thought of English lesson, my mind came to the moment when my teacher painted the formula of " $\mathrm{S}+\mathrm{V}+\mathrm{O}$ " on the board.

P4: When I think of English courses I took in secondary education or in high school, I recall that communication was not given any importance. Perhaps, it was a situation that originated from my teacher. But even though I read the preparatory class in high school, I would found myself talking in class at most 2 or 3 times a week.

P16: During high school and pre-school, we were confronted with a teacher image constantly conveying information to us on the board. The teacher was not directing the lecture but was in direct charge of information transfer in general. Even though the university has put us in a more active role, I would still like to have more lessons to improve our speaking skills here. In fact, I think that even if there are some of us to develop communicative skills, they are more of a selftaught, self-taught person who have developed themselves through self-efforts.

P28: When I think of the trainings I have taken so far, maybe at university it was a bit better - but we have not done much work to get us to talk. Rather, we would have had to work on solving test questions.

However, although some more negative ideas were put forward about the 'ignored' emphasis of communicative activities in Turkish formal education context, some of the participants shared the idea that "Speaking and listening skills has gained importance in recent years" with new developments when compared to the previous years.

In conclusion, pre-service EFL teachers interviewed seemed to be seriously pessimistic about the emphasis of communicative competence in the education system they are planning to be enrolled as teachers in the future. Their complaints about the lack of emphasis on communicative skills in their previous education signals to the fact that EFL learners expect to be exposed to and use the target language they are going to teach.

\subsection{Turkish EFL Student Teachers' Beliefs about Communicative Approach and its Practicality in Turkish Formal Education System}

The mean values of participants' attitudes towards the communicative approach according to gender, department and age groups, and whether the differences between these means are meaningful or not were analysed by using Mann Whitney U Test in independent groups for gender and departments, and Kruskal Wallis for age groups. Whether the level of participation on the basis of expressions varied depending on gender was analysed and the results were given in Table 3 .

Table 3.

Beliefs about CA by Gender

\begin{tabular}{lrrrrr}
\hline Gender & & $\mathrm{N}$ & Mean Rank & Sum of Rank & $p$ \\
\hline Communicative & Female & 234 & 222.31 & 52021.50 & \multirow{2}{*}{.905} \\
\cline { 2 - 4 } Approach & Male & 211 & 223.76 & 47213.50 & \\
\hline
\end{tabular}

The mean participation level about the communicative approach is 223.76 for males while the mean level of participation in the females is 222.31. It seems there is no significant difference between the mean levels of participation in expressions for the communicative approach of males and females $(p=.905)$. Table 3 also shows that the pre-service EFL teacher participants seem to have positive beliefs about the Communicative Approach regardless of gender. Whether the level of participation varied depending on the departments was also analysed. Table 4 shows that the mean level for the communicative approach is 187.23 for ELL students while it is 255.56 for ELT 
students. There is a significant difference between ELL and ELT students' mean levels of participation in the communicative approach $(p=.001)$. The level of participation of ELT students is significantly greater than the level of participation of ELL students. Based on the data in Table 2, it can be argued that ELT students are more likely to adopt the communicative approach in their teaching activities. This difference in the attitudes of both groups could be resulted from the curriculum variation between these two departments.

Table 4.

Beliefs about CA by Departments

\begin{tabular}{lccccc}
\hline Department & & $\mathrm{N}$ & Mean Rank & Sum of Rank & $p$ \\
\hline Communicative & ELL & 234 & 187.23 & 29505.00 & \multirow{2}{*}{$.001^{*}$} \\
\cline { 2 - 5 } Approach & ELT & 211 & 255.56 & 59430.50 & \\
\hline${ }^{*} p<0.05$ & & & & &
\end{tabular}

Whether the level of participation varied by age groups was also analysed. Table 5 shows that the mean levels of participation for communicative approach is 235.64 for the 20-22 age group students, 219.30 for the 23-25 age group students, and 141.70 for $26+$ age group students in the range of 1-5. There is a significant difference between participation levels of the communicative approach for age groups $(p=.019)$. According to the results of the non-parametric pairwise comparison post-hoc test conducted to determine the group from which the difference originated, the participation level of 20-22 age group students seemed to be significantly higher than the other two groups. There was no significant difference between participation levels of the 23-25 and 26+ age groups.

Table 5.

Beliefs about CA by Age Groups

\begin{tabular}{|c|c|c|c|c|}
\hline & Age Groups & $\mathrm{N}$ & Mean Rank & $p$ \\
\hline \multirow{3}{*}{$\begin{array}{l}\text { Communicative } \\
\text { Approach }\end{array}$} & $20-22$ & 172 & 235.64 & \multirow{3}{*}{$.019^{*}$} \\
\hline & $23-25$ & 258 & 219.30 & \\
\hline & $26+$ & 15 & 141.70 & \\
\hline
\end{tabular}

When their ideas about communicative approach were asked, the participants' answers varied to some degree depending on their perceptions about it. Yet, among 28 participants, some of their ideas showed similarity to each other. The most common perception of the participants was that it was an approach targeting "communication" essentially. 10 of the 28 participants stated that " $C A$ promotes communicative skills".:

P2: CA is an approach that aims to improve communicative skills at first glance.

P7: However, if these problems can be overcome, it will greatly support communication skills.

P28: It may be very beneficial in terms of communicative skills provided that the teacher is mastered in the target language and good model for the students.

P22: The approach itself is very nice to the ear and evokes communicative skills.

P27: Problems put aside, a nice approach that promotes communication in itself.

P28: Possible to success in developing communicative skills...

Considering the traditional methods putting the teacher in the centre of the learning and teaching environment, one of the most common idea about the approach was that "It is a relatively more student cantered approach". Additionally, some ideas such as "Skills of teachers are very crucial in this approach", "It requires practice in real life", "Cognitive readiness should not be ignored", "Teachers should be skilled at speaking", and "Age variables should be considered" were shared during the interviews. Besides, from the point of the teachers, participants regarded it as an enjoyable approach to adopt and use in the classroom. 
However, there were some negative ideas about communicative approach as well. The issue of "central exams" was an important distracting factor for the participants. Six participants stated that "Central examinations may influence the development of communicative competence negatively". Also, the idea that "It may increase teachers' workload" is shared by 5 participants. This statement was made considering the fact that teachers had already existing excessive workloads at government schools. Additionally, the idea that "Practicing in real life is hard in countries like Turkey" is yet another negative idea shared by 5 participants. Finally, another very frequent response is given by 5 participants who stated that "Regional differences may cause problem in application", which is an issue related to economic conditions. Even if the classroom equipment of government schools is provided by central authority for every part of the country, some regions with better facilities have advantages over.

Pre-service EFL teachers' beliefs about the practicality of the communicative approach in Turkish formal education system was also analysed qualitatively within the light of the data obtained through focus-group interviews. When their ideas about the suitability of the communicative approach in Turkish formal education system were asked, the participants ${ }^{\text {ee }}$ answers varied to some degree depending on their perceptions. There were 28 participants in the interview and the most common response was "New course books facilitate its applicability". Apart from it, there seemed to be not any other idea in favour of CA in Turkish context. 4 of the participants agreed on the idea that "But for the external factors, it may be useful". As it is not possible to avoid all the external factors immediately, even this favouring one seemed to be a rather negative idea. Yet, 8 participants stated that "It seems like a utopic approach for Turkish formal education system". That is to say, despite believing in its effectiveness in developing communicative competence, CA is thought not to be a suitable approach in Turkish formal education system. The idea that "Classes are too crowded in government schools to apply" was stated by 7 participants. Communicative activities and assessment methods offered by CA seemed to be acceptable only in uncrowded classrooms according to the participants. Also, in addition to physical conditions, the fact that most Turkish teachers are more accustomed to teaching in traditional methods and their influence was predominant over less traditional teachers who believe the power of CA were also the case. To depict commonly viewed ideas:

P3: I think the suitability of it to the system is open to discussion. Because the approach that works anywhere in the world may not work elsewhere. Above all, the vast majority of teachers in the education system have grown up learning English through traditional methods. I cannot expect these teachers to quickly adapt themselves to new developments. At least, in-service training is a must.

P13: I think implementing private institutions, courses or at least government schools in preparatory classes can have very fruitful results. But in the current system it is unlikely to be implemented in state schools, especially in intermediate classes.

P19: I think it is very difficult to apply our educational system, which is teacher-centred, with exam-oriented work for all lessons, not only in English. Although it seems to be very successful within itself, I think the situation can be a little challenging in our system.

P22: At present there are technical subdivisions to better implement the Communicative Approach at school, but as my friends have said, teachers cannot effectively use these enhancements as a negative reflection of pre-university or college education. They are influenced by traditional approaches.

P25: It can be a really utopic approach in an education system where students who are going to win the future with exams that cannot measure communicative competence are raised.

\subsection{The extent to which Turkish EFL student teachers feel self-efficient in communicative approach}

The mean values of participants' Self-Efficacy beliefs in communicative approach according to gender, department and age groups, and whether the differences between these means are 
meaningful or not were analysed by using Mann Whitney U Test in independent groups for gender and departments, and Kruskal Wallis for age groups.

As Table 6 shows, the mean participation level in the self-efficacy beliefs about the communicative approach is 225.64 for females, and the mean level of participation in the males is 220.07. There is no significant difference between the average levels of participation in Self-Efficacy beliefs about the communicative approach of males and females $(p=.644)$. Also, in consideration of the data Table 2 shows, both groups seem to have positive ideas about their self-efficiency levels in their grasp about CA.

Table 6.

Self-Efficacy Beliefs in CA by Gender

\begin{tabular}{lllcccc}
\hline & Gender & N & Mean Rank & Sum of Rank & $p$ \\
\hline \multirow{2}{*}{ Self-Efficacy Beliefs in CA } & Female & 234 & 225.64 & 52800.50 & \multirow{2}{*}{.644} \\
\cline { 2 - 5 } & Male & 211 & 220.07 & 46434.50 & \\
\hline
\end{tabular}

As Table 7 shows, the mean participation level in the Self-Efficacy beliefs about the communicative approach is 201.07 for ELL students while the mean level of participation in the ELT students is 242.77. There is a significant difference between ELL and ELT students' level of participation in Self-Efficacy beliefs about the communicative approach $(p=.001)$. The level of participation of ELT students is significantly higher than the level of participation of ELL students. Also, Table 2 above shows that the level of participation of ELT students is at the "agree" level while the level of participation of ELL students is between "neutral" and "agree". Yet, the reason for this significance could not be clarified at this point. In further studies focusing on curriculum differences or preference differences between the students of each department, the reason for this significant difference could be analysed in detail.

Table 7.

Self-Efficacy Beliefs in CA by Departments

\begin{tabular}{lrrrcc}
\hline & Department & $\mathrm{N}$ & Mean Rank & Sum of Rank & $p$ \\
\hline \multirow{2}{*}{ Self-Efficacy Beliefs in CA } & ELL & 234 & 201.07 & 42426.00 & \multirow{2}{*}{$.001^{*}$} \\
\cline { 2 - 5 } & ELT & 211 & 242.77 & 56809.50 & \\
\hline
\end{tabular}

${ }^{*} p<0.05$

As Table 8 shows, the mean level of participation in their self-efficacy beliefs in the communicative approach is 233.05 for the 20-22 age group students, 238.52 for the $23-25$ age group students, and 230.33 for $26+$ age group students in the range of 1-5. There is no significant difference between age groups' level of participation Self-Efficacy beliefs about the communicative approach $(p=.066)$.

Table 8.

Self-Efficacy Beliefs in CA by Age Groups

\begin{tabular}{lrrcc}
\hline & Age Groups & $\mathrm{N}$ & Mean Rank & \\
\hline \multirow{3}{*}{ Self-Efficacy Beliefs in CA } & $20-22$ & 172 & 233.05 & \\
\cline { 2 - 5 } & $23-25$ & 258 & 238.52 & \multirow{2}{*}{066} \\
\cline { 2 - 4 } & $26+$ & 15 & 230.33 & \\
\hline
\end{tabular}

As Table 9 shows, the mean participation level in the EFL self-efficacy beliefs expressions is 220.67 for males and the mean level of participation in the females is 225.10 . There is no significant difference between the average levels of participation in EFL self-efficacy beliefs expressions of males and females $(p=.715)$. Also, in consideration of the data in Table 2 above, it is seen that both groups are somewhat higher than the level of "agree". This result seems normal considering 
the fact that most of the pre-service EFL teachers seem to feel self-efficient in their EFL proficiency levels.

Table 9

Self-Efficacy Beliefs in EFL Skills by Gender

\begin{tabular}{lrcccc}
\hline & Gender & $\mathrm{N}$ & Mean Rank & Sum of Rank & $p$ \\
\hline $\begin{array}{l}\text { Self-Efficacy Beliefs in EFL } \\
\text { Skills }\end{array}$ & Female & 234 & 225.10 & 52673.50 & \multirow{2}{*}{.715} \\
\cline { 2 - 5 } & Male & 211 & 220.67 & 46561.50 & \\
\hline
\end{tabular}

As Table 10 shows, the mean participation level in the EFL Self-Efficacy beliefs expressions is 233.73 for ELL students while the mean level of participation in the ELT students is 213.32. There is no significant difference between ELL and ELT students' level of participation in EFL self - efficacy beliefs expressions $(p=.092)$. As the on Table 2 shows, the participation levels of both ELL and ELT students are somewhat higher than the level of "agree". The fact that participants enrolled at both ELL and ELT department feel self-efficient in their EFL proficiencies may not mean that they all feel self-confident on the same skills. For seeing whether there is a difference in their beliefs in certain skills, each skill including Listening, Speaking, and Reading, Writing, Grammar knowledge and Target culture knowledge were analysed separately according to departments.

Table 10.

Self-Efficacy Beliefs in EFL Skills by Departments

\begin{tabular}{lrrrrr}
\hline & Department & $\mathrm{N}$ & Mean Rank & Sum of Rank & $p$ \\
\hline Self-Efficacy Beliefs in EFL & ELL & 234 & 233.73 & 49317.50 & \multirow{2}{*}{092} \\
\cline { 2 - 5 } Skills & ELT & 211 & 213.32 & 49917.50 & \\
\hline
\end{tabular}

As Table 11 shows, the mean level of participation in the EFL Self-Efficacy beliefs expressions is

223.19 for the 20-22 age group students, 226.18 for the 23-25 age group students, and 166.10 for $26+$ age group students in the range of 1-5. There is no significant difference between age groups' level of participation in EFL self-efficacy beliefs expressions $(p=.208)$. As the data in Table 2 shows, the level of participation of all age groups is at the "agree" level.

Table 11.

Self-Efficacy Beliefs in EFL by Age Groups

\begin{tabular}{|c|c|c|c|c|}
\hline & roups & $\mathrm{N}$ & Mean Rank & $p$ \\
\hline \multirow{3}{*}{$\begin{array}{l}\text { Self-Efficacy Beliefs in EFL } \\
\text { Skills }\end{array}$} & $20-22$ & 172 & 223.19 & \multirow{3}{*}{.208} \\
\hline & $23-25$ & 258 & 226.18 & \\
\hline & $26+$ & 15 & 166.10 & \\
\hline
\end{tabular}

When the correlation between perceptions about CA and Self-Efficacy beliefs in CA is analysed as Table 12 shows, a meaningful correlation was found between these two notions with a level of $40.6 \%$. It could be argued that pre-service EFL teachers' self-efficacy beliefs about "Department" have a significant influence on the attitudes towards it. From this point, referring to the significant difference between the self-efficacy beliefs of ELL and ELT students in CA; and the significant difference between the perceptions of ELL and ELT departments about CA, it could be said that the reason why ELT students have better attitudes towards CA is because of the fact that they feel better at CA when compared to ELL students, or vice versa.

Table 12.

Correlation between CA Beliefs and CA Self-Efficacy Beliefs

\begin{tabular}{llc}
\hline & \multicolumn{2}{c}{ Self-Efficacy beliefs in CA } \\
\hline \multirow{2}{*}{ Communicative Approach Beliefs } & $r$ & $.406^{* *}$ \\
\cline { 2 - 3 } & $p$ & .000 \\
\hline
\end{tabular}


This correlation seems to support the idea that the extent to which a certain subject or skill is believed to be efficient has a significant influence on the way it is perceived. When the correlation between EFL self-efficacy beliefs and communicative approach self-efficacy beliefs is analysed as Table 13 shows, a meaningful correlation is found between these two notions with a level of $19.1 \%$.

Table 13.

Correlation between Self-Efficacy in CA and EFL

\begin{tabular}{lll}
\hline & \multicolumn{2}{c}{ Self-Efficacy Beliefs in Communicative Approach } \\
\hline \multirow{2}{*}{ Self-Efficacy beliefs in EFL } & $r$ & $.191^{* *}$ \\
\cline { 2 - 3 } & $p$ & .000 \\
\hline
\end{tabular}

From this point, it could be argued that pre-service EFL teachers' Self-Efficacy beliefs in EFL have a significant influence on their Self-Efficacy beliefs in CA implementation. In other words, the more they feel efficient in EFL, the more they feel self-efficient in CA.

\section{Discussion, Conclusion and Implications}

We investigated the beliefs of pre-service EFL teachers about communicative skills development in a foreign language through communicative approach within Turkish formal education system. Our first question provided insights into the participants" beliefs about "communicative competences", and its emphasis in the Turkish formal education system. Most pre-service EFL teachers regarded communicative competence as a phenomenon related mostly with spoken language in the light of the qualitative data obtained from the focus group interviews. Also, even while speaking, being able to get across an idea in one way has precedence over fluency and structural patterns according to the participants. Yet, even if there were some emphasizing the importance of fluency and structural proficiency, most participants agreed upon the idea that "being able to express oneself well enough" was the primary requirement of communicative competence. Additionally, the participants thought that the emphasis for communicative competence development is ignored in Turkish formal education system. The reason for this was partly due to the central exams and lack of emphasis on the other aspects of communicative skills including meaning/semantics and performance/pragmatics in Turkish education system. This result is concurrent with Altan's (2017b) argument that the problem Turkish EFL learners have in communicative perspective is at meaning/semantics and performance/pragmatics with a portion of two out of three also including form/structure.

Our next question (2nd question) found out pre-service EFL teachers' beliefs about the communicative approach and its practicality in Turkish context. The mean values of the participants were found to have positive attitudes towards CA regardless of the external factors they think to face in actual teaching. Yet, when compared to ELL students, ELT students were found to have significantly more positive attitudes towards CA despite the fact that they are both at agree level with the positive statements about the approach. Additionally, younger prospective teachers were found to have more positive attitudes towards CA when compared to older ones. This finding is in parallel with the results of a study conducted with 14 teachers from different secondary and high schools by Çimen (2008). This type of difference may result from the fact that younger ones are more exposed to the approach than the older ones as it is gaining more dominance in Turkish education system year by year. Pre-service EFL teachers' beliefs about the practicality of CA in Turkish formal education system were analysed qualitatively, and as a result, we found that even though they had positive beliefs about CA and considered themselves as being knowledgeable about its theoretical framework, this doesn't necessarily mean they regarded it as an applicable approach to implement in Turkish context. There are similar findings with various other research studies on CA in Turkish context (Arıbaş \& Tok, 2004; Bağceci \& Yaşar, 2007; Çimen, 2008; Diler, 2013; Karapirinler, 2006; Soğuksu, 2013; Şeker \& Aydın, 2011; Yılmaz, 2005). Such factors as "central exam anxiety, economic limitations, parental interferences" are considered to be the major inhibiting factors for the implementation of CA in Turkish government schools. We 
conclude that any approach that suits one part of the world may be quite unsuitable for another part. Yet, regional modifications could be useful to solve the problems. Otherwise, pre-service EFL teachers seem to be pessimistic towards CA's suitability in Turkish government schools even if they seem to have positive attitudes towards it.

In response to the third research question, the participants reported that they are efficient enough to implement CA in their classes with some amount of improvement as they are at agree level by a narrow margin. Yet, ELT students were found to believe themselves to be more efficient in CA compared to ELL students. This finding is supported by Y1ldirim and İlhan (2010), who noted that self-efficacy does not mean that a person is talented, but that he has confidence in his own capacity and he has sufficient skills to deal with a situation but who has low self-sufficiency and who cannot act on his/her skills.

The beliefs towards CA were found to be influenced by the extent to which they feel efficient in the approach. The fact that ELT students both have more positive attitudes towards CA and feel more efficient in CA while ELL students are both less positive towards and have less positive beliefs about the approach provide empirical data supporting this correlation. Additionally, the levels at which pre-service EFL teachers feel self-efficient in their EFL skills were found to have a significant influence on their self-efficacy beliefs in CA. This could be explained by the fact that proficiency belief in one phenomenon depends on the proficiency belief in subdivisions of it. Succession in this issue depends on one's self-perception on this efficacy. This judgement, named as "Self-Efficacy Beliefs" by Bandura (1986), is referred to a teacher's beliefs about being whether sufficient or not for organizing and carrying out the classes in such a way that the teaching tasks could be achieved successfully. Self-efficacy beliefs of the teachers are believed to have an indisputable impact on the qualities of the teachers (Bandura, 1997; Pajares, 1992).

One implication for the study is that regardless of the genders, departments and age groups, the pre-service EFL teachers put considerable emphasis on communicative skills development. However, pre-service EFL students seem to have no self-confidence about how they would apply this into their classes. Even if it is the approach integrated into foreign language education in Turkey, the communicative approach needs to be modified to Turkish context in such a way that the external inhibitions should be minimized. In the face of difficulties regarding the implementation of CA due to several external factors, we suggest that traditional methods and communicative approach can be combined with the efficient use of both communicative and noncommunicative activities as learners"e previous learning habits and external factors cannot be excluded in an instant, a suggestion also supported by İnceçay and İnceçay (2009). It is also the case that there are some differences between ELT and ELL departments in terms of their selfefficacy beliefs not only in CA implementation but also in their EFL proficiency levels for specific skills, and further studies should be carried out focusing on the curricula of the departments. Moreover, according to Gültekin et al. (2010), most of the pre-service EFL teachers feel pessimistic about the negative attitudes of their colleagues as a result of their experiences in teaching practices and we suggest that in-service training should be carried out continuously for EFL teachers to help them keep pace with the innovations in EFL teaching.

Acknowledgement. The study was orally presented in VIIth International Eurasian Educational Research Congress ONLINE 10 - 13 September 2020 | Anadolu University, and this is an extended and original version of the oral presentation.

\section{References}

Akpınar, B., \& Aydın, K. (2010). Çok duyulu (multi sensory) yabancı dil öğretimi. Tübav Bilim Dergisi, 2(1), 99-106.

Aktimur, D. (2007). İletişimci yaklaşımda konuşma ve okuma becerileri: İletişimci yaklaşımla konuşma ve okuma becerilerinin birleştirilerek genç öğreniciler için ikili etkinlik ve grup etkinlikleriyle pekiştirilmesi (Unpublished Ma Thesis). Ankara University, Institute of Social Sciences. Ankara, Turkey.

Akyel, A. (2015). Research engagement in the EFL pre-service practicum. Language in Focus, 1(1), 1-14. 
Aliş, E. (2008). The effect of professional experiences and English self-efficacy beliefs of Yildiz Technical University School of Foreign Languages Department of Basic English Instructors on their communicative language teaching attitudes (Published MA Thesis). Y1ldiz Technical University, Institute of Social Sciences, Istanbul, Turkey.

Altan, M. Z. (2010). ELT major university students' beliefs on the role of English, Globalization and Global English. In Gagliardi, C, Maley, A. (Eds), EIL, ELF, Global English: Teaching and Learning Issues (pp. 321340). Bern: Peter Lang AG.

Altan, M. Z. (2017a). Globalization, English language teaching and Turkey. International Journal of Languages' Education and Teaching, 5, 764-776.

Altan, M. Z. (2017b). Yabancı Dil: Neden Öğretemiyoruz. Neden Öğrenemiyoruz. Eğitime Bakış, 39(1), 12-24.

Altınuç, Z. (2012). English teachers' perception of communicative language teaching-a qualitative research (Unpublished Ma Thesis). Yeditepe University, Institute of Social Sciences, Istanbul, Turkey.

Arıbaş, S., \& Tok, H. (2004, July). Evaluating the problems encountered in foreign languages instruction in the first level of elemantary school. Paper presented at XIII. Ulusal Eğitim Bilimleri Kurultayı, İnönü Üniversitesi, Eğitim Fakültesi, Malatya, Turkey.

Bachman, L. F. (1990). Fundamental considerations in language testing. Oxford: Oxford University Press.

Bağçeci, B. (2004, July). Ortaöğretim kurumlarnnda İngilizce öğretimine ilişkin öğrenci tutumlari (Gaziantep ili örneği). Paper presented at XIII. Ulusal Eğitim Bilimleri Kurultayı, İnönü Üniversitesi, Eğitim Fakültesi, Malatya, Turkey.

Bağçeci, B. \& Yaşar, M. (2007). Opinions of students attending high schools in Gaziantep about the teaching of English. Gaziantep Üniversitesi Sosyal Bilimler Dergisi, 6(1), 9-16.

Bandura, A. (1977). Self-efficacy: toward a unifying theory of behavioral change. Psychological Review, 84(2), 191-215.

Bandura, A. (1986). Social foundations of thought and action: a social cognitive theory. NJ: Prentice-Hall, Englewood Cliffs.

Bauch, P. A. (1982). Relationships between a typology of teacher educational beliefs and three domains of the elementary classroom curriculum. A Study of Schooling Technical Report No. 34. (ERIC Document Reproduction Service No. ED269346).

Beck, U. (2002). The cosmopolitan society and its enemies. Theory, culture \& society, 19(1-2), 17-44.

Bottery, M. (2000). Education, policy and ethics. London: A\&C Black.

Breen, M. P., \& Candlin, C. N. (1980). The essentials of a communicative curriculum in language teaching. Applied linguistics, 1(2), 89-112.

Brookhart, S. M., \& Freeman, D. J. (1992). Characteristics of entering teacher candidates. Review of educational research, 62(1), 37-60.

Brown, H. D. (2000). Principles of language learning and teaching (Vol. 4). New York: Longman.

Buchmann, M. (1984). The use of research knowledge in teacher education and teaching. American Journal of Education, 92(4), 421-439.

Byram, M. (1997). Teaching and assessing intercultural communicative competence. Clevedon, UK: Multilingual Matters.

Canale, M., \& Swain, M. (1980). Theoretical bases of communicative approaches to second language teaching and testing. Applied linguistics, 1(1), 1-47.

Celce-Murcia, D., \& Dornyei, Z. (2014). Communicative Competence: A Pedagogically Motivated Model with Content Specifications. Issues in Applied Linguistics, 1(1), 1-47.

Celce-Murcia, M., Brinton, D. M., \& Snow, M. A. (2020). Teaching English as a second or foreign language (4th edition). Heinla Cengage Learning.

Chang, J. (2006). Globalization and English in Chinese higher education. World Englishes, 25(3-4), 513-525.

Clark, C. M. (1988). Asking the right questions about teacher preparation: Contributions of research on teacher thinking. Educational Researcher, 17(2), 5-12.

Cohen, L. \& Manion, L. (1994). Research methods in education. London: Routledge.

Crystal, D. (2003). English as a global language. Cambridge: Cambridge University Press.

Çimen, C. (2008). The comparison of senior and junior language teachers' awareness of Communicative Language Teaching (CLT) background theory, in Turkey (Unpublished MA Thesis). Abant İzzet Baysal University, Bolu, Turkey.

Deckert, G. (1987). The communicative approach: Helping students adjust. In English Teaching Forum 25(3), 17-20.

Dijk, T. A. (2014). Discourse and knowledge: A sociocognitive approach. Cambridge: Cambridge University Press. 
Diler, U. (2013). The communicative approach in English language classes: How communicative are they? (Doctoral Dissertation). Istanbul Aydin University, Institute of Social Sciences, Istanbul, Turkey.

Dörnyei, Z., \& Taguchi, T. (2009). Questionnaires in second language research: Construction, administration, and processing. Routledge.

Emeli, D. (1999). The Communicative approach and its implications to grammar teaching and learning (Unpublished Ma Thesis). Çukurova University, Institute of Social Sciences, Adana, Turkey.

Enochs, L. G., \& Riggs, I. M. (1990). Further development of an elementary science teaching efficacy belief instrument: A preservice elementary scale. School Science and Mathematics, 90(8), 694-712.

Fang, Z. (1996). A review of research on teacher beliefs and practices. Educational research, 38(1), 47-65.

Goodman, J. (1988). Constructing a practical philosophy of teaching: A study of preservice teachers' professional perspectives. Teaching and teacher education, 4(2), 121-137.

Gültekin, M., Çubukçu, Z., \& Dal, S. (2010). İlköğretim öğretmenlerinin eğitim öğretimle ilgili hizmetiçi eğitim gereksinimleri. Selçuk Üniversitesi Ahmet Keleşoğlu Ĕ̆itim Fakültesi Dergisi, 29, 131-152.

Haney, J. J., Lumpe, A. T., Czerniak, C. M., \& Egan, V. (2002). From beliefs to actions: The beliefs and actions of teachers implementing change. Journal of science teacher education, 13(3), 171-187.

Horwitz, E. K. (1985). Using student beliefs about language learning and teaching in the foreign language methods course. Foreign Language Annals, 18(4), 333-340.

Hui, L.,\& Jin, G. (2010). Communicative method in language teaching. US-China Foreign Language, 8(5), 33-37.

Hunter, M. (1982). Mastery teaching. CA: Corwin Press, Thousand Oaks.

Hymes, D. (1971). On linguistic theory, communicative competence, and the education of disadvantaged children. In M. L. Wax, S. Diamon. and F. O. Gearing (Eds.). Anthropological perspectives on education (pp. 51-66), New York: Basic Books.

Hymes, D. (1972). Competence and performance in linguistic theory. Language acquisition: Models and methods, 1, 3-28.

İnceçay, G., \& İnceçay, V. (2009). Turkish university students' perceptions of communicative and noncommunicative activities in EFL classroom. Procedia-social and Behavioral Sciences, 1(1), 618-622.

Kachru, B. B. (1986). The alchemy of English: The spread, functions, and models of non-native Englishes. Oxford: Pergamon and Urbana: University of Illinois Press.

Karapirinler, E. (2006). Özel ilköğretim okullarinda ikinci yabanci dil ögretimi (Unpublished doctoral dissertation). Ankara University, Turkey.

Kırkgöz, Y. (2007). English language teaching in Turkey: Policy changes and their implementations. RELC journal, 38(2), 216-228.

Larsen-Freeman, D. (2000). Techniques and principles in language teaching (2nd Edition). Oxford: Oxford University Press.

Levin, T., \& Wadmany, R. (2005). Changes in educational beliefs and classroom practices of teachers and students in rich technology-based classrooms. Technology, Pedagogy and Education,14(3), 281-307.

Liao, X. (1997). A brief introduction to the communicative language teaching. Technical report. (ERIC Document Reproduction Service No. ED404863).

Littlewood, W. T. (1981). Communicative language teaching: An introduction. Cambridge: Cambridge University Press.

Mak, S. H. Y. (2011). Tensions between conflicting beliefs of an EFL teacher in teaching practice. RELC Journal, 42(1), 53-67.

Nishino, T. (2012). Modeling teacher beliefs and practices in context: A multimethods approach. The Modern Language Journal, 96(3), 380-399.

Oral, Y. (2003). Reflections of the global English in Turkey (An intercultural approach and a critical Approach) (Unpublished MA Thesis), İstanbul Üniversitesi, İstanbul.

Özoğlu, M. (2010). Türkiye' de öğretmen yetiştirme sisteminin sorunları. Seta Analiz, 17(26), 131-155.

Özşevik, Z. (2010). The use of communicative language teaching (CLT): Turkish EFL teachers' perceived difficulties in implementing CLT in Turkey (Unpublished MA thesis). University of Illinois, The USA.

Pajares, M. F. (1992). Teachers' beliefs and educational research: Cleaning up a messy construct. Review of Educational Research, 62(3), 307-332.

Raoofi, S., Tan, B. H., \& Chan, S. H. (2012). Self-efficacy in second/foreign language learning contexts. English Language Teaching, 5(11), 60-73.

Richards, J. C. (1992). Dictionary of language teaching and applied linguistics (2nd edition). Longman.

Richards, J. C., \& Rodgers, T. S. (2001). Approaches and methods in language teaching (2 ${ }^{\text {nd }}$ edition). Cambridge: Cambridge University Press. 
Richards, J. C. (2006). Communicative language teaching today. New York: Cambridge University Press.

Savignon, S. (1983). Communicative competence: Theory and classroom practice. Reading, MA: Addison-Wesley Publishing Company.

Skehan, P. (1998). A cognitive approach to language learning. Oxford: Oxford University Press.

Soğuksu, A. F. (2013). Reflection of the communicative approach adopted in the secondary curriculum for English in the classroom (Unpublished MA Thesis). Ankara University, Institute of Educational Sciences, Ankara, Turkey.

Swales, J. (1997). Genre analysis: English in academic and research settings. Cambridge University Press.

Şeker, E., \& Aydın, İ. (2011). İngilizce dil öğretim yöntemi olarak iletişimsel yaklaşım: Van Atatürk Anadolu Lisesi örneği. Pegem Ĕ̆itim ve Öğretim Dergisi, 1(1), 39-49.

Şimşek, H., \& Yıldırım, A. (2011). Sosyal bilimlerde nitel araştırma yöntemleri. Ankara: Seçkin Yayıncllık.

Tayhani-Temizgöl, T. (2013). The effects of grammar translation method and communicative language teaching on vocabulary teaching (Unpublished Doctoral dissertation). Dokuz Eylul University, Institute of Educational Sciences, Izmir, Turkey.

Temizöz, H. (2008). Yabancı dil öğretiminde dilbilgisi çeviri yöntemi ve iletişimci yaklaşım uygulamalarının ögrrencilerin öğrenme becerisi üzerindeki etkisi (Unpublished MA Thesis). Inönü University, Institute of Social Sciences, Malatya, Turkey.

Weir, C. J. (1998). Communicative language testing. Exeter: University of Exeter Press.

Wilson, S. M. (1990). The secret garden of teacher education. Michigan: National Center for Research on Teacher Education.

Woolley, S. L., Benjamin, W. J. J., \& Woolley, A. W. (2004). Construct validity of a self-report measure of teacher beliefs related to constructivist and traditional approaches to teaching and learning. Educational and Psychological Measurement, 64(2), 319-331.

Yıldırım, F., \& İlhan, İ. Ö. (2010). Genel öz yeterlilik ölçeği Türkçe formunun geçerlilik ve güvenilirlik çalışması. Türk Psikiyatri Dergisi, 21(4), 301-308.

Yılmaz, C. (2005). İngilizce öğretmenliği öğrencilerinin yabancı dili iletişim aracı olarak kullanabilme yeterlilikleri. Erzincan Ĕ̆itim Fakültesi Dergisi, 7(1), 15-23.

Zheng, H. (2009). A review of research on EFL pre-Service teachers' beliefs and practices. Journal of Cambridge Studies, 4(1), 73-81. 